\title{
HUBUNGAN KEMAMPUAN PENALARAN MATEMATIS DAN MOTIVASI BELAJAR SISWA SMK MELALUI MODEL PEMBELAJARAN HYPNOTEACHING
}

\author{
Agfie Nurani Hanifah ${ }^{1}$, Nurholipatus Sa'adah², Agung Dwi Sasongko ${ }^{3}$ \\ $1,2,3$ Universitas Pasundan, Jl. Sumatera No. 41, Kota Bandung, Indonesia \\ email: agfienuranih.anh@gmail.com
}

\begin{abstract}
The purpose of this research is to examine how the relationship between mathematical reasoning abilities with student motivation in learning using hypnoteaching models. This research method is a quasi-experimental method, with two different classes taken, where the first class gets learning with hypnoteaching models and the second class uses ordinary learning. The population is all students in one vocational school in Bandung regency with a sample taken by two classes. Both classes are given a pretest and an initial questionnaire to find out their initial abilities, then in the experimental class learning is given with hypnoteaching models and the control class is given regular learning, and at the end of both classes are given a posttest and also a final questionnaire, where the final data will be processed and analyzed the correlation using Pearson Product Moment. The results showed a significant relationship between mathematical reasoning abilities with student learning motivation in learning mathematics.
\end{abstract}

Keywords: Mathematical Reasoning, Motivation to Learn, Hypnoteaching

\section{ABSTRAK}

Tujuan penelitian ini adalah untuk menelaah bagaimana hubungan antara kemampuan penalaran matematis dengan motivasi belajar siswa dalam pembelajaran yang menggunakan model hypnoteaching. Metode penelitian ini adalah metode kuasi eksperimen, pengambilan sampel dua kelas yang berbeda, dimana kelas pertama mendapatkan pembelajaran dengan model hypnoteaching dan kelas kedua menggunakan pembelajaran biasa. Populasinya yaitu seluruh siswa pada salah satu SMK di kabupaten Bandung dengan pengambilan sampel dua kelas. Masing-masing kelas diberikan pretes dan angket awal untuk mengetahui kemampuan awal mereka, selanjutnya pada kelas eksperimen diberikan pembelajaran dengan model hypnoteaching dan kelas kontrol diberikan pembelajaran biasa, dan di akhir kedua kelas diberikan postes dan juga angket akhir, yang mana data di akhir tersebut akan di olah dan di analisis korelasinya menggunakan Product Moment Pearson. Hasil penelitian menunjukkan adanya hubungan yang signifikan antara kemampuan penalaran matematis dengan motivasi belajar siswa dalam proses pembelajaran matematika.

Kata Kunci: Penalaran Matematis, Motivasi belajar, Hypnoteaching

Dikirim : 24 September 2019; Diterima: 26 September 2019; Dipublikasikan : 30 September 2019

Cara sitasi: Hanifah, A. N., Sa'adah, N., \& Sasongko, A. D. (2019). Hubungan kemampuan penalaran matematis dan motivasi belajar siswa smk melalui model pembelajaran hypnoteaching. Teorema: Teori dan Riset Matematika, 4(2), 121-130.

rсINUAпULUhIV 
Hamalik (2011) menyatakan Pendidikan merupakan suatu proses yang mempengaruhi peserta didik agar mampu menyesuaikan diri dengan lingkungannya. Dengan demikian maka akan menimbulkan perubahan dalam diri anak yang memungkinkan mereka berfungsi secara efektif dalam kehidupan masyarakat. Mereka bertugas mengarahkan proses belajar agar sasaran dari perubahan itu tercapai sebagaimana yang diinginkan.

Salah satu mata pelajaran yang diajarkan di sekolah yaitu matematika memiliki tempat tersendiri dan menjadi fokus utama yang sangat penting di setiap sekolah. Karena matematika telah berpengaruh besar pada pendidikan dan kemajuan teknologi. Dalam bidang pendidikan formal di lingkungan sekolah khususnya, matematika dijadikan sebagai salah satu acuan standar dalam kelulusan. Oleh karena itu, pentingnya para siswa mempelajari matematika.

Sejalan dengan hal ini, Depdiknas (2002) menyatakan bahwa materi pembelajaran matematika dan komunikasi matematika serta penalaran matematis mempunyai keterkaitan yang sangat kuat dan tidak dapat dipisahkan. Materi matematika dipahami dan dikomunikasikan melalui penalaran, selanjutnya penalaran dipahami dan dilatih melalui belajar matematika. Dengan belajar matematika, keterampilan penalaran siswa akan meningkat karena pola berpikir yang dilatih dalam matematika melibatkan pemikiran yang kritis, sistematis, logis, dan kreatif.

Sariningsih (2014) mengatakan bahwa dalam pelajaran matematika dibutuhkan inovasi yang dapat menumbuhkan dan mengembangkan potensi yang dimiliki siswa, salah satunya yaitu mengasah kemampuan penalaran matematis siswa. Menurut Keraf (1982) kemampuan penalaran matematis dapat diartikan sebagai proses berpikir yang berusaha menghubungkan fakta-fakta yang diketahui menuju kepada suatu kesimpulan. Copi (sumartini, 2015) menyatakan bahwa penalaran adalah bentuk khusus dari berpikir dalam upaya pengambilan kesimpulan konklusi yang digambarkan premis. Galloti (1989) mengatakan bahwa penalaran menstransformasikan informasi yang diberikan untuk menelaah konklusi. Sejalan dengan itu, Somatanaya (2017) mengatakan bahwa kemampuan penalaran diperlukan agar peserta didik memiliki kemampuan memperoleh, mengelola, dan memanfaatkan infomasi untuk bertahan hidup pada keadaan yang selalu berubah, tidak pasti, dan kompetitif. Dapat dikatakan bahwa penalaran merupakan daya pikir seseorang dalam menarik dan menyimpulkan sesuatu.

Ironisnya matematika dikalangan para peserta didik merupakan mata pelajaran yang kurang disenangi, motivasi mereka terhadap matematika masih tergolong rendah sehingga penguasaan peserta didik terhadap mata pelajaran matematika menjadi sangat kurang. Tidak mudah membuat peserta didik menyukai, fokus dan betah dalam proses belajar mengajar matematika.

Pada kenyataannya kemampuan penalaran matematis siswa masih tergolong rendah. Terbukti berdasarkan data yang diperoleh dari nilai rata-rata peserta didik masih berada dibawah KKM sebagai berikut:

\begin{tabular}{|c|c|c|}
\hline Tahun Ajaran & Rata-rata & KKM \\
\hline $2017 / 2018$ & 60 & 70 \\
\hline $2018 / 2019$ & 65 & 70 \\
\hline $2019 / 2020$ & 63 & 70 \\
\hline
\end{tabular}

Sumber: nilai ujian akhir siswa kelas X RPL SMK Marhas Margahayu

Selain kemampuan kognitif, kemampuan afektif yang harus dikembangkan dalam pembelajaran matematika adalah sikap, karena sikap merupakan faktor yang sangat mempengaruhi perilaku seseorang dalam menghadapi suatu tugas (Zakiah, 2017). Salah satu yang menjadi penyebabnya adalah rendahnya motivasi belajar siswa terhadap pembelajaran matematika. Menurut James O.Whittaker (Soemanto, 2006) motivasi merupakan kondisi yang mengaktifkan tingkah laku agar mencapai tujuan yang ditimbulkan oleh motivasi tersebut, sedangkan belajar adalah proses dimana tingkah laku tersebut diubah melalui latihan atau pengalaman. Sedangkan pengertian belajar menurut Slameto (2013) yaitu proses usaha yang dilakukan individu untuk memperoleh perubahan tingkah laku secara keseluruhan dalam interaksi dalam lingkungan. Sejalan dengan itu, Hakim 
(2018) berpendapat bahwa salah satu faktor yang mempengaruhi prestasi belajar matematika peserta didik adalah motivasi belajar.

Pada saat pembelajaran berlangsung, siswa merasa takut terlebih dahulu sebelum belajar. Kebanyakan siswa menganggap pembelajaran matematika sulit sehingga tidak tertarik pada saat pembelajaran matematika sedang berlangsung di dalam kelas. Salah satu cara untuk mengatasi masalah tersebut adalah dengan menerapkan model pembelajaran yang bisa meningkatkan motivasi belajar peserta didik terhadap pembelajaran matematika, salah satu model pembelajaran yang dapat meningkatkan motivasi belajar peserta didik tersebut adalah model pembelajaran hypnoteaching.

Model pembelajaran yang mampu membuat siswa merasa suka dan tertarik dengan pelajaran matematika dan mampu menciptakan kondisi dimana siswa berkonsentrasi penuh terhadap pelajaran matematika salah satunya adalah hypnoteaching. Hypnoteaching merupakan teknik menggabungkan antara ilmu hypnosis, komunikasi, psikologi dan teknik pengajaran di kelas.

Model pembelajaran hypnoteaching merupakan suatu model pembelajaran yang dalam penyampaian materinya, guru memakai bahasa alam bawah sadar yang bisa menumbuhkan ketertarikan tersendiri terhadap siswa. Hajar (Catur, 2013) mengemukakan bahwa hypnoteaching merupakan seni berkomunikasi dengan jalan memberikan sugesti agar para siswa menjadi lebih cerdas. Hypnoteaching merupakan perpaduan pembelajaran yang melibatkan antara pikiran dalam keadaan sadar dan pikiran alam bawah sadar. Diantari (2014) berpendapat bahwa hypnoteaching ini merupakan pembelajaran yang unik, kreatif, menarik sekaligus imajinatif.

Inti dari hypnoteaching adalah suatu proses seorang guru mampu menggunakan bahasabahasa yang dapat membuat rileks dan nyaman peserta didik dengan intonasi teratur yang maknanya persuasif penuh bujukan dilihat baik dari kualitas vokal maupun pilihan kata-katanya yang tidak boleh menggunakan kata "akan" dan bermakna negatif seperti "tidak dan jangan". Ketika peserta didik berada dalam keadaan otak alpha, saat itu guru memasukkan affirmasi positif atau sugesti positif kepada pikiran bawah sadar siswa.

Berdasarkan pengalaman yang dialami oleh penulis bahwa pembelajaran Matematika anak usia dini yang berorientasi pada model pembelajaran hypnoteaching akan membantu anak untuk berimajinasi yang menekankan pikiran bawah sadar seseorang sehingga mampu menimbulkan ideide yang lebih baik ketika diarahkan ke hal positif dan dapat meningkatkan tingkat berpikir yang akan tersimpan dengan baik.

Berdasarkan uraian di atas, penulis tertarik melihat hubungan antara dua kemampuan tersebut, yang diharapkan adalah jika terjadi peningkatan pada motivasi belajar siswa maka terjadi pula peningkatan pada kemampuan penalaran matematis siswa. Selanjutnya, penulis ingin melakukan pengembangan dalam bentuk penelitian yang berjudul "Hubungan Kemampuan Penalaran Matematis Dan Motivasi Belajar Siswa SMK Melalui Model Pembelajaran Hypnoteaching".

\section{METODE PENELITIAN}

Metode penelitian yang digunakan pada penelitian ini adalah kuasi eksperimen, tujuan penelitian ini untuk melihat hubungan antara kemampuan penalaran matematis dan motivasi belajar siswa menggunakan model pembelajaran hypnoteaching. Subjek dalam penelitian ini adalah siswa kelas XI SMK Marhas Margahayu Kabupaten Bandung dimana diambil sampel dua buah kelas, kelas yang pertama (eksperimen) menggunakan model pembelajaran hypnoteaching dan kelas kedua (kontrol) menggunakan pembelajaran konvensional. Instrumen yang digunakan yaitu instrumen tes kemampuan penalaran matematis dan angket motivasi belajar siswa. Angket motivasi pada penelitian ini digunakan untuk mengukur dan mengetahui motivasi belajar matematika siswa kelas XI SMK Marhas Margahayu Kabupaten Bandung dalam mengikuti pembelajaran 
menggunakan metode hypnoteaching. Skor angket dan instrumen tes yang diperoleh kemudian di uji korelasi menggunakan Product Moment Pearson.

Teknik analisis data yang dilakukan dalam penelitian ini adalah angket motivasi dan lembar observasi. Teknik pengumpulan data dengan cara observasi ini bertujuan untuk mengetahui keterlaksanaan pembelajaran matematika menggunakan metode hypnoteaching. Adapun yang diamati pada saat observasi adalah sebagai berikut

Tabel 2. Langkah-langkah dalam metode Hypnoteaching

\begin{tabular}{|c|c|c|}
\hline No & Langkah-langkah Metode Hypnoteaching & Aspek yang Diamati \\
\hline 1 & Niat dan Motivasi & $\begin{array}{l}\text { Guru memerintahkan kepada siswa untuk } \\
\text { berdoa sebelum pembelajaran }\end{array}$ \\
\hline & & $\begin{array}{l}\text { Guru memberi motivasi kepada siswa bahwa } \\
\text { pembelajan matematika sangat pentng untuk } \\
\text { dipelajari dalam kehidupan sehari-hari }\end{array}$ \\
\hline 2 & Pacing & $\begin{array}{l}\text { Guru menggunakan bahasa-bahasa yang } \\
\text { mudah dipahami oleh siswa dan sedikit selipkan } \\
\text { bahsa gaul yang dipakai oleh guru agar siswa } \\
\text { tidak merasa takut pada saat proses } \\
\text { pembelajaran. }\end{array}$ \\
\hline 3 & Leading & $\begin{array}{l}\text { Guru mengarhkan pada tujuan pembelajaran } \\
\text { dan memimpin diskusi kelompok peserta didik }\end{array}$ \\
\hline 4 & Menggunakan kata-kata positif & $\begin{array}{l}\text { Guru menggunakan kata-kata positif pada saat } \\
\text { proses pembelajaran }\end{array}$ \\
\hline 5 & Memberikan Pujian & $\begin{array}{l}\text { Guru memberikan reward atau penguatan } \\
\text { kepada peserta didik melalui kata-kata atau } \\
\text { gerak tubuh }\end{array}$ \\
\hline 6 & Modelling & $\begin{array}{l}\text { Guru memberikan contoh yang baik kepada } \\
\text { peserta didik melalui ucapan }\end{array}$ \\
\hline 7 & Menguasai Materi Secara Komprehensif & Guru memberikan materi secara konstektual \\
\hline
\end{tabular}

\section{HASIL DAN PEMBAHASAN}

Hakim (2018) mengatakan bahwa dengan hypnoteaching memudahkan untuk memahami dan mencerna setiap materi pembelajaran karena hypnoteaching menekankan pada komunikasi alam bahawa sadar, baik yang dilakukan dalam kelas maupun luar kelas. Hal ini dilakukan dengan sugesti dan imajinasi.

Adapun hipotesis pada penelitian ini adalah "Terdapat hubungan yang positif antara kemampuan penalaran matematis dan motivasi belajar siswa SMK dalam pembelajaran yang menggunakan model pembelajaran hypnoteaching". Untuk menguji hipotesis tersebut, maka dilakukan uji korelasi. Sebelum melakukan uji korelasi tersebut, terlebih dahulu dilakukan uji normalitas sebagai prasyarat, apabila data berdistribusi normal maka dilanjutkan dengan uji korelasi Product Moment Pearson dan apabila data tidak berdistribusi normal maka digunakan uji korelasi Spearman. Berikut adalah langkah-langkah dalam pengujian hipotesis pada penelitian ini: 


\section{Uji Normalitas Data Kelas Kontrol}

Hipotesis yang akan diuji:

$H_{0}$ : Data kemampuan penalaran matematis dan motivasi belajar kelas kontrol berdistribusi normal

$H_{1}$ : Data kemampuan penalaran matematis dan motivasi belajar kelas kontrol tidak berdistribusi normal

Berikut ini hasil dari analisis uji normalitas:

Tabel 3. Hasil Uji Normalitas Kemampuan Penalaran Matematis dan Motivasi Belajar Kelas dengan Pembelajaran Biasa (Kontrol)

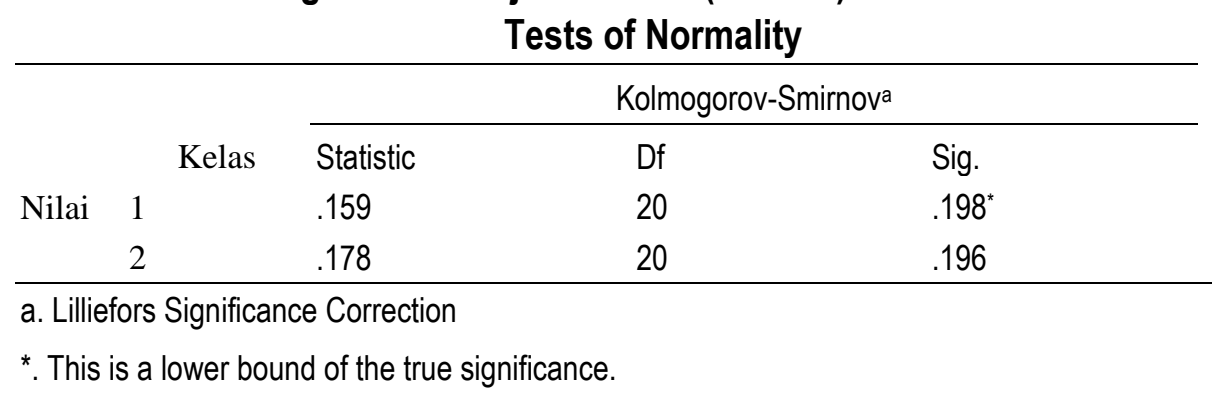

Kriteria pengambilan keputusan uji normalitas adalah sebagai berikut:

1) Apabila nilai signifikansi lebih kecil dari 0,05 maka $H_{0}$ ditolak

2) Apabila nilai signifikansi lebih besar sama dengan 0,05 maka $H_{0}$ diterima

Dari Tabel 3 di atas, didapatkan nilai signifikansi uji Kolmogorov Smirnov pada skor postes kemampuan penalaran matemamatis kelas kontrol yaitu $0,198 \geq 0,05$, begitupun untuk skor motivasi belajar siswa kelas kontrol yaitu $0,196 \geq 0,05$, maka $H_{0}$ diterima. Artinya data postes kemampuan penalaran matemamatis dan skor motivasi belajar siswa kelas pada pembelajaran biasa berdistribusi normal.

\section{Uji Normalitas Data Kelas Eksperimen}

Hipotesis yang akan diuji:

$H_{0}$ : Data kemampuan penalaran matematis dan motivasi belajar kelas eskperimen berdistribusi normal

$H_{1}$ : Data kemampuan penalaran matematis dan motivasi belajar kelas eskperimen tidak berdistribusi normal

Berikut ini hasil dari analisis uji normalitas:

Tabel 4. Hasil Uji Normalitas Kemampuan Penalaran Matematis dan Motivasi Belajar Kelas Eksperimen

\begin{tabular}{ccccc} 
& \multicolumn{3}{c}{ Tests of Normality } \\
\hline \multirow{3}{*}{ Nilai } & Kelas & Statistic & Df & Sig. \\
\cline { 2 - 5 } & 1 & .174 & 20 & $.113^{\star}$ \\
& 2 & .202 & 20 & .087 \\
\hline
\end{tabular}

a. Lilliefors Significance Correction

*. This is a lower bound of the true significance.

Kriteria pengambilan keputusan uji normalitas adalah sebagai berikut: 
1) Apabila nilai signifikansi lebih kecil dari 0,05 maka $H_{0}$ ditolak

2) Apabila nilai signifikansi lebih besar sama dengan 0,05 maka $H_{0}$ diterima

Dari Tabel 4 di atas, ternyata nilai signifikansi uji Kolmogorov Smirnov pada skor postes kemampuan penalaran matematis kelas eksperimen yaitu $0,113 \geq 0,05$ begitu juga untuk skor motivasi belajar siswa kelas eksperimen yaitu $0,087 \geq 0,05$, maka $H_{0}$ diterima. Artinya data postes kemampuan penalaran matematis dan skor motivasi belajar siswa kelas eksperimen berdistribusi normal.

\section{Uji Korelasi Kemampuan Penalaran Matematis dan Motivasi Belajar Siswa dalam Matematika}

Perhitungan sebelumnya telah diketahui bahwa baik data kelas kontrol maupun kelas eksperimen berdistribusi normal. Untuk mengetahui seberapa kuat hubungan antara kemampuan penalaran matematis dan motivasi belajar siswa pada pembelajaran matematika digunakan uji Korelasi Product Moment Pearson dengan taraf signifikansi 0,05.

\section{a) Kelas Kontrol}

Berikut adalah hipotesis yang digunakan untuk menguji hipotesis penelitian nomor 4 pada halaman 55:

$H_{0}$ : tidak terdapat hubungan signifikan antara kemampuan penalaran matematis dan motivasi belajar siswa kelas kontrol

$H_{1}$ : terdapat hubungan signifikan antara kemampuan penalaran matematis dan motivasi belajar siswa kelas kontrol

Kriteria pengujian yang digunakan adalah:

1) Apabila signifikansi nilainya lebih besar sama dengan 0,05 maka $H_{0}$ diterima

2) Apabila signifikansi nilaiya lebih kecil dari 0,05 maka $H_{0}$ ditolak

Hasil pengolahan korelasi ditunjukkan pada tabel berikut:

Tabel 5. Hasil Uji Korelasi antara Kemampuan Penalaran Matematis dan Motivasi Belajar Siswa Kelas Kontrol

\begin{tabular}{|c|c|c|c|}
\hline \multicolumn{4}{|c|}{ Correlations } \\
\hline & & $\begin{array}{l}\text { Postes penalaran } \\
\text { kelas kontrol }\end{array}$ & $\begin{array}{l}\text { Angket motivasi } \\
\text { belajar kelas } \\
\text { kontrol }\end{array}$ \\
\hline \multirow{3}{*}{$\begin{array}{l}\text { Postes } \\
\text { kontrol }\end{array}$} & kelas Pearson Correlation & 1 & $.763^{* *}$ \\
\hline & Sig. (2-tailed) & & .000 \\
\hline & $\mathrm{N}$ & 20 & 20 \\
\hline \multirow{3}{*}{$\begin{array}{l}\text { Angket motivasi } \\
\text { kelas kontrol }\end{array}$} & belajar Pearson Correlation & $.763^{* *}$ & 1 \\
\hline & Sig. (2-tailed) & .000 & \\
\hline & $\mathrm{N}$ & 20 & 20 \\
\hline
\end{tabular}

**. Correlation is significant at the 0.05 level (2-tailed).

Dari Tabel 5, diperoleh hasil korelasi antara kemampuan penalaran matematis dan motivasi belajar siswa kelas kontrol sebesar 0,763 dan nilai signifikansi sebesar 0,000 Harga korelasi $(r)$ yang diperoleh adalah 0,763 yang artinya tingkat hubungannya tergolong tinggi. Karena nilai signifikansi 0,000 kurang dari 0,05 maka terdapat hubungan signifikan antara kemampuan penalaran matematis dan motivasi belajar siswa kelas kontrol.

\section{b) Kelas Eksperimen}


Berikut adalah hipotesis yang digunakan untuk menguji hipotesis dalam penelitian ini:

$H_{0}$ : tidak terdapat hubungan signifikan antara kemampuan penalaran matematis dan motivasi belajar siswa kelas eksperimen

$H_{1}$ : terdapat hubungan signifikan antara kemampuan penalaran matematis dan motivasi belajar siswa kelas eksperimen

Kriteria pengujian yang digunakan adalah:

1) Apabila signifikansi nilainya lebih besar dari 0,05 maka $H_{0}$ diterima

2) Apabila signifikansi nilaiya lebih kecil dari 0,05 maka $H_{0}$ ditolak

Hasil pengolahan korelasi ditunjukkan pada tabel berikut:

Tabel 6. Hasil Uji Korelasi antara Kemampuan Penalaran Matematis dan Motivasi Belajar Siswa Kelas Eksperimen

\begin{tabular}{|c|c|c|c|}
\hline \multicolumn{4}{|c|}{ Correlations } \\
\hline & & $\begin{array}{l}\text { Postes penalaran } \\
\text { kelas kontrol }\end{array}$ & $\begin{array}{l}\text { Angket motivasi } \\
\text { belajar kelas } \\
\text { kontrol }\end{array}$ \\
\hline \multirow{3}{*}{$\begin{array}{l}\text { Postes } \\
\text { kontrol }\end{array}$} & kelas Pearson Correlation & 1 & $.873^{* *}$ \\
\hline & Sig. (2-tailed) & & .000 \\
\hline & $\mathrm{N}$ & 20 & 20 \\
\hline \multirow{3}{*}{$\begin{array}{l}\text { Angket motivasi } \\
\text { kelas kontrol }\end{array}$} & belajar Pearson Correlation & $.873^{* *}$ & 1 \\
\hline & Sig. (2-tailed) & .000 & \\
\hline & $\mathrm{N}$ & 20 & 20 \\
\hline
\end{tabular}

**. Correlation is significant at the 0.05 level (2-tailed).

Dari Tabel 6, diperoleh hasil korelasi antara kemampuan penalaran matematis dan motivasi belajar siswa kelas eksperimen adalah 0,873 dan nilai signifikansi sebesar 0,000 Harga korelasi $(r)$ yang diperoleh adalah 0,873 yang artinya tingkat hubungannya tergolong tinggi. Karena nilai signifikansi 0,000 kurang dari 0,05 maka terdapat hubungan yang signifikan antara kemampuan penalaran matematis dan motivasi kelas eksperimen.

Pada kedua kelas, baik kelas eksperimen (pembelajarannya menggunakan model pembelajaran hypnoteaching) maupun kelas kontrol (menggunakan pembelajaran biasa) terjadi hubungan yang sama-sama tergolong tinggi, antara kemampuan penalaran matematis dan motivasi belajar yang dimiliki oleh siswa. Namun, hasil korelasi pada kelas eksperimen yang diperoleh dari postes dan angket akhir yang diberikan setelah pembelajaran dengan menggunakan model hypnoteaching terlihat lebih besar dibandingkan dengan hasil postes dan angket akhir siswa yang menggunakan pembelajaran biasa. Artinya, pada kelas eksperimen terjadi semakin tinggi kemampuan penalaran matematis siswa maka semakin tinggi pula motivasi belajar yang dimiliki siswa. Berbeda dengan kelas kontrol, jika kemampuan penalaran matematis siswanya rendah, maka demikian pula dengan motivasi belajar yang dimiliki oleh siswa.

Dari analisis tersebut, dapat kita tarik kesimpulan, bahwa dalam pembelajaran matematika yang menggunkan model pembelajaran hypnoteaching akan meningkatkan kemampuan penalaran matematis siswa, dan juga berdampak langsung pada peningkatan motivasi belajar yang dimiliki oleh siswa. 


\section{KESIMPULAN}

Simpulan yang dapat diambil dari penelitian ini adalah terdapat hubungan positif dan signifikan antara kemampuan penalaran matematis dengan motivasi belajar baik pada siswa yang yang mendapatkan pembelajaran dengan model pembelajaran hypnolearning maupun siswa yang mendapatkan pembelajaran matematika biasa.

Saran yang dapat disampaikan adalah aspek yang diukur pada penelitian ini hanya minat belajar. Minat belajar yang ditelaah pada penelitian ini merupakan minat belajar yang terkait dengan kompetensi keahlian siswa dan mendukung pula kemampuan penalaran matematis. Peneliti selanjutnya sebaiknya meneliti minat belajar siswa yang terkait dengan kemampuan matematis lainnya, atau kemampuan penalaran matematis dengan aspek-aspek yang lain.

\section{REKOMENDASI}

Berdasarkan penelitian dan pembahasan peneliti memberikan beberapa saran:

1. Pembelajaran dengan model hypnolearning dapat meningkatkan kemampuan penalaran matematis siswa dibandingkan dengan pembelajaran konvensional maka disarankan pembelajaran menggunakan model pembelajaran hypnolearning diterapkan pada materi-materi matematika yang lain.

2. Pembelajaran dengan model hypnolearning dapat dibiasakan untuk digunakan dalam pembelajaran sehari-hari karena dapat mengubah pola pikir siswa untuk lebih berpikir posituf terhadap matematika dan yang paling utama adalah dapat meningkatkan minat belajar siswa.

\section{UCAPAN TERIMAKASIH}

Penulis mengucapkan terimakasih kepada H. Bana G. Kartasasmita, Ph.D dan In In Supianti, M.Pd selaku dosen yang selalu membimbing dan mengarahkan sehingga penelitian ini dapat berjalan dengan lacar. Tak lupa penulis ucapkan terimakasih kepada Hj. Siti Maryam, S.H., M.M. selaku kepala sekolah SMK Marhas Margahayu yang telah mendukung dalam penelitian ini sehingga peneliti dapat melakukan penelitian dengan lancar.

\section{DAFTAR PUSTAKA}

Depdiknas. (2002). Kurikulum Berbasis Kompetensi Mata Pelajaran Matematika. Jakarta: Pusat Kurikulum Balitbang.

Diantari, P. (2014). Pengaruh Model Pembelajaran Problem Based Learning Berbasis Hypnoteaching Terhadap Hasil Belajar Matematika Siswa Kelas V SD. Jurnal Mimbar PGSD Universitas Pendidikan Ganesha.

Galotti, K.M. (1989). Approaches to studying Formal and Everyday Reasoning. Psychology Bulettin.

Hamalik, Oemar. (2011). Kurikulum dan Pembelajaran. Jakarta: Bumi Aksara.

Hakim, A. R., Sulistiawati, S., \& Arifin, S. (2018). Hubungan Antara Kecerdasan Emosional Dan Motivasi Belajar Dengan Prestasi Belajar Matematika Siswa SMP. Teorema: Teori dan Riset Matematika, 3(2), 165-176.

Keraf, G. (1982). Argumentasi dan narasi: Komposisi lanjutan III (Vol 3). Gramedia

Sariningsih, R. (2014). Pendekatan kontekstual untuk meningkatkan kemampuan pemahaman matematis siswa SMP. Infinity Journal, 3(2), 150-163. 
Slameto. (2013). Belajar dan faktor-faktor yang mempengaruhinya. Jakarta: PT Rineka Cipta.

Soemanto, W. (2006). Psikologi Pendidikan: Landasan Kerja Pemimpin Pendidikan (Cetakan Ke 5). Jakarta: Rineka Cipta.

Somatanaya, A. G. (2017). Analisis Kemampuan Berfikir Nalar Matematis Serta Kontribusinya Terhadap Prestasi Belajar Mahasiswa (Studi Terhadap Mahasiswa FKIP Pendidikan Matematika Universitas Siliwangi). Teorema: Teori dan Riset Matematika, 1(2), 55-62.

Sumartini, T.S (2015). Peningkatan Kemampuan Penalaran Matematis Siswa Melalui Pembelajaran Berbasis Masalah. Jurnal Pendidikan Matematika.

Zakiah, N. E. (2017). Pembelajaran dengan pendekatan kontekstual berbasis gaya kognitif untuk meningkatkan self awareness siswa. Teorema: Teori dan Riset Matematika 2(1), 11-20. http://dx.doi.org/10.25157/teorema.v2i1 
•130 Teorema: Teori dan Riset Matematika, 4(2), 121-130, September 2019 